\title{
De la confusión una invitación
}

\section{And Invitation from confusion}

Estons

stimados lectores y colaboradores de la revista Cirujano General,

hemos detectado en redes sociales una creciente inconformidad por la demora en el proceso editorial, incluso de hasta dos años, y por la falta de información sobre la etapa en que se encuentran sus contribuciones. Es preciso aclarar que se nos reclama lo anterior confundiendo Cirujano General con otra prestigiada revista de cirugía en México.

Me es grato informarles que nuestros procesos, a pesar de las complicaciones, son relativamente ágiles en comparación con otras revistas y que, como bien saben, hemos logrado, además de que se desarrollen de manera adecuada, sacar adelante el rezago heredado de administraciones anteriores.

Nuestro compromiso con ustedes es que la revista Cirujano General siga incrementando su difusión y la calidad de sus contenidos, pero también que todo el proceso editorial sea eficiente. Para ello es necesario que la comunidad de cirujanos colabore con nosotros. Específicamente invito a los revisores a corresponder de manera activa con ese compromiso y a los colaboradores a atender oportunamente las sugerencias y correcciones. El proceso no depende sólo de una casa ni de un editor, sino también de la celeridad de todos, revisores y colaboradores, para ajustarse a los tiempos de entrega.

Aprovecho entonces además de aclarar la situación, que no es adversa sino una oportunidad, para invitarlos a seguir proponiendo colaboraciones de calidad y, en particular, para responder lo más pronto posible, pues una revista dinámica conviene a todos. Nuestra meta común es que la revista Cirujano General se convierta en un referente de la cirugía en México.

Reitero a ustedes la invitación con un saludo muy cordial.

Dra. Abilene C. Escamilla Ortiz Editora, Revista Cirujano General. 